\title{
Relacijska družinska terapija kot ena od metod kompleksne rehabilitacije otrok z motnjo hiperaktivnosti in pozornosti ter njihovih družin
}

Teja Bandel*

Univerzitetni rehabilitacijski inštitut RS - Soča, Center za poklicno rehabilitacijo

Povzetek: Motnja hiperaktivnosti in pozornosti (ADHD) je ena od najbolj pogostih duševnih motenj, ki se pojavljajo pri otrocih, in se kaže v obliki težav s pozornostjo ter s simptomi hiperaktivnosti in impulzivnosti, simptomatika pa se ponavadi v nekoliko spremenjeni obliki nadaljuje v obdobja mladostništva in odraslosti. Otroci imajo lahko poleg omenjenega pridružene duševne motnje ali pa težave na posameznih področjih spoznavnega, čustvenega, socialnega ali zdravstvenega delovanja, posledice pa občutijo tudi člani družine. Dejavniki, ki prispevajo k pojavu motnje so različni in mnogoteri, možne oblike obravnav pa obsegajo terapijo z medikamenti, nevrofeedback, družinske intervence in družinsko terapijo. Avtorica na osnovi pregleda novejše znanstvene literature o značilnostih dinamike v družinah z otrokom z ADHD in že uporabljanih družinskih pristopih za zdravljenje predlaga in utemeljuje obravnavo teh otrok in njihovih družin z metodo relacijske družinske terapije.

Ključne besede: motnja pomanjkanja pozornosti s hiperaktivnostjo, psihološka obravnava, družinski odnosi, relacijska družinska terapija

\section{Relational family therapy as one of the methods for complex rehabilitation of children with attention deficit/hyperactivity disorder and their families}

\author{
Teja Bandel
}

\begin{abstract}
Attention-deficit/hyperactivity disorder (ADHD) is one of the most common mental disorders in the childhood. It's a persistent and severe impairment of psychological development resulting from a high level of inattentive, hyperactive and impulsive behaviour and puts sufferers at risk for a range of abnormalities in different areas of development as well as comorbid mental disorders. The adverse outcomes include dysfunction in familiy relations. ADHD likely involves both genetic and environmental etiologies. Treatments most frequently used are medication, neurofeedback, family interventions and family therapy. The review of recent scientific literature refering dynamics in families with ADHD children and family relations based treatments may propose relational family therapy as one of the possible interventions.
\end{abstract}

Key words: attention deficit disorder with hyperactivity, psychological assessment, family relations, relational family therapy

\footnotetext{
${ }^{*}$ Naslov/Address: mag. Teja Bandel, Univerzitetni rehabilitacijski inštitut RS - Soča, Center za poklicno rehabilitacijo, Linhartova cesta 51, 1000 Ljubljana, e-mail: teja.bandel@ir-rs.si
}

Članek je licenciran pod pogoji Creative Commons Attribution 4.0 International licence. (CC-BY licenca).

The article is licensed under a Creative Commons Attribution 4.0 International License (CC-BY license). 


\section{Motnja pozornosti in hiperaktivnosti pri otrocih}

ADHD oz. motnja pozornosti s hiperaktivnostjo vključuje razvojni starosti otroka neustrezne simptome hiperaktivnosti, impulzivnosti in težav s pozornostjo. Oviranost zaradi simptomov se mora pojavljati vsaj v dveh različnih okoljih (npr. doma in v šoli) (American Psychiatric Association, 2000). Motnja ADHD je bolj pogosteje diagnosticirana pri dečkih kot pri deklicah, v razmerju dečki:deklice od 4:1 do 9:1. Prisotna je pri 3-5 \% šolajočih se otrok (American Psychiatric Association, 2000; Barkley, 1998b). Pojavlja se pri ljudeh ne glede na starost, spol, raso ali kulturno ozadje (Everett in Everett, 1999). V zahodnih kulturah se odstotek diagnosticiranih $v$ zadnjem času zvišuje, verjetno predvsem zaradi različnih diagnostičnih praks, kot pa zaradi dejanske povečane pojavnosti (American Psychiatric Association, 2000).

Simptomatika se lahko kaže že v zgodnjem otroštvu, sprva bolj kot nezrelo in težko obvladljivo splošno otrokovo vedenje ter nepredvidljivo odzivanje. Ponavadi je diagnoza prvič postavljena ob otrokovem vstopu v šolo, ko je potrebna prilagoditev na šolsko okolje in so obremenitve ter zahteve po samoobvladovanju večje, okviri norm socialnega vedenja pa ožji, kot jih je bil otrok do tedaj navajen (American Psychiatric Association, 2000; Tomori, 1999).

Tipi ADHD po DSM IV (Diagnostic and Statistical Manual of Mental Disorders, 4th Edition, text revision, American Psychiatric Association, 2000) so naslednji: kombiniran tip (motnja pozornosti in hiperaktivnosti), tip, kjer se pretežno pojavljajo težave $v$ pozornosti in tip, kjer se pretežno pojavljata hiperaktivnost in impulzivnost. Tip neopredeljenih težav s pozornostjo in hiperaktivnostjo pa opisuje osebe, ki imajo simptome hiperaktivnosti in pomanjkanja pozornosti kot rezultat pridobljene poškodbe možganov, bolezni, zastrupitev, so starejši od 60 let ali pa ne spadajo v nobeno od zgornjih kategorij. Simptomi morajo vztrajati vsaj 6 mesecev, prisotnih pa mora biti vsaj 6 posameznih kriterijev nepozornosti, hiperaktivnosti in impulzivnosti (npr. pogosto se zdi, da ne posluša osebe, ki mu želi nekaj sporočiti; pogosto ima težave z organiziranjem nalog in aktivnosti; pogosto ima nemirne roke in noge ali se zvija na stolu; pogosto zmoti ali se vmešava v pogovor oz. igro; pogosto zapušča stol v učilnici ali v drugih situacijah, v katerih je pričakovano mirno sedenje itd.). Mednarodna klasifikacija bolezni in sorodnih zdravstvenih problemov za statistične namene (Moravec Berger in Kovačič, 2005), pa tako deli motnjo ADHD: hiperkinetične motnje, motnja aktivnosti in pozornosti, hiperkinetična motnja vedenja, druge vrste hiperkinetična motnja in neopredeljena hiperkinetična motnja.

\section{$Z$ ADHD povezane težave in pridružene motnje}

Opisane značilnosti motnje ADHD lahko pri otroku resno zmotijo šolanje in proces socializacije ter ga pogosto spravljajo v napetost in konflikte $\mathrm{z}$ domačimi, učitelji in vrstniki. Tako zmanjšana šolska uspešnost kot vedenjska problematika in težave $\mathrm{v}$ odnosih $\mathrm{z}$ najbližjimi so lahko izvor mnogih pridruženih spoznavnih, čustvenih in vedenjskih motenj. Izraznost motnje je tekom osnovnega šolanja relativno stabilna, $\mathrm{v}$ času mladostništva in odraslosti pa se predvsem simptomi hiperaktivnosti zmanjšajo, čeprav ima manjšina teh oseb tudi v odraslosti prisotne vse simptome ADHD, kot npr. nezmožnost organiziranja časa in dejavnosti, nevztrajnost, nestrpnost in hitra razburljivost (American Psychiatric Association, 2000; Barkley, 1998c; Tomori, 1999).

Otroci z ADHD imajo oškodovano spoznavno delovanje na različnih področjih, kot na primer intelektualni razvoj (Faraone idr., 1993; Fischer, Barkley, Edelbrock in Smallish, 1990; Lynam, Moffitt in Stouthamer-Loeber, 1993; Moffitt, 1990; Seidman, Biederman, Faraone, Weber in Ouellette, 1997; Zhang, Jin in Zhang, 2011), delovni spomin (Barkley, 1997; Barkley, DuPaul in McMurray, 1990), odkrenljivost pozornosti (Landau, Lorch in Milich, 1992; Pennington, Groisser in Welsh, 1993), izvršitvene funkcije (Oosterlaan, Scheres in Sergeant, 2005) itd. Otroci s pozunanjenimi težavami, kamor spada tudi motnja ADHD, imajo vsaj 1,5 -krat več nenamernih poškodb $\mathrm{v}$ primerjavi s splošno populacijo otrok (Brehaut, Miller, Rain in McGrail, 2002; DiScala, Lescohier, Barthel in Li, 1998). Večina študij opisuje medosebne odnose otrok z ADHD z drugimi kot težavne zaradi pomanjkljivih socialnih spretnosti (Fussell, Macias in Saylor, 2005; Heiman, 2005; Nixon, 2001; Stormont, 2001), obstajajo pa tudi raziskave, ki te trditve empirično ne podprejo (Wiener, 2004). Motnja ADHD se pri otrocih $\mathrm{v}$ večji meri povezuje $\mathrm{z}$ nemirom $\mathrm{v}$ učilnici in zmanjšano odpornostjo proti izzivanju s strani vrstnikov (Frankel in Feinberg, 2002), otroci z ADHD so pogosteje tarča nasilja (Holmberg in Hjern, 2008), imajo težave pri pridobivanju prijateljev, obdržati prijateljstvo in pri kvaliteti teh odnosov (tj. da prijatelji niso vpleteni $\mathrm{v}$ deviantne aktivnosti) (Mikami, 2010), prejemajo nizke ocene v sociometričnih preizkušnjah (Guvremont in Dumas, 1994), so vsiljivi, nasilni, moteči in vihravi (Landau in Moore, 1991), kršijo pravila, se kregajo in izkazujejo verbalno ter fizično agresijo (Guevremont in Dumas, 1994).

Skupki posameznih težav na različnih področjih delovanja oseb se združujejo v večje in bolj kompleksne sindrome, ki so del uradno priznanih duševnih oz. telesnih motenj. Otroci $\mathrm{z}$ ADHD imajo tako zaradi mnogih $\mathrm{z}$ motnjo povezanih težav posledično tudi dodatne diagnoze na področju težav v duševnem zdravju. Okrog $44 \%$ otrok z ADHD se jih sreča z vsaj eno, skoraj tretjina jih ima dve in približno ena desetina tri pridružene motnje (Everett in Everett, 1999; Szatmari, 
Offord in Boyle, 1989). Kljubovalna in vedenjska motnja sta najpogostejši spremljevalni motnji ADHD (od 33 $\%$ do $50 \%$ ) (American Psychiatric Association, 2000; Biederman, Newcorn in Sprich, 1991; Spencer, 2009). Anksiozne in depresivne motnje se pri teh otrocih pojavljajo v približno petindvajsetih odstotkih (American Psychiatric Association, 2000; Guttmann-Steinmetz, Gadow, DeVincent in Crowell, 2010; Root in Resnick, 2003; Sorensen, Plessen, Nicholas in Lundervold, 2011; Spencer, 2009; Tomori, 1999). Nekateri otroci z ADHD imajo ob vstopu $\mathrm{v}$ šolo specifične učne težave (do 22 \%) (American Psychiatric Association, 2000; McGee in Share, 1988; Snider, Frankenburger in Aspenson, 2000). Otroci z ADHD imajo pogosto težave v senzomotorični koordinaciji, ki se kažejo predvsem kot težave s pisanjem, nespretnost, slabi športni dosežki in zaostanki v motoričnem razvoju (Gillberg, 2003; Kadesjo in Gillberg, 2001; Tomori, 1999). Nekateri avtorji pri mladostnikih in odraslih, ki imajo diagnosticiran ADHD že od otroštva, opažajo višjo pojavnost odvisnosti od psihoaktivnih substanc, zgodnejše poseganje po drogah (Greene, Biederman, Faraone, Sienna in Garcia-Jetton, 1997; Huss in Lehmkuhl, 2002; Spencer, 2009), bolj pogosto in intenzivno uživanje droge, več zlorabe alkohola in večkratna neuspela zdravljenja od odvisnosti (Lynskey in Hall, 2001; Wilens, Biederman, Mick, Faraone in Spencer, 1997). Pri otrocih z ADHD se pogosto (npr. pri do $73 \%$; Sung, Hiscock, Sciberras in Efron, 2008) pojavljajo tudi motnje spanja.

\section{Dejavniki tveganja za nastanek motnje ADHD ter vzajemno vplivanje družinske dinamike in motnje}

Specifična etiologija za ADHD ostaja slabše definirana, čeprav je v zadnjem času prišlo do precejšnjega napredka v okviru nevrobioloških raziskav. Dejavnike tveganja za pojav ADHD pri otrocih lahko grobo razdelimo na biološke in psihosocialne. Večina študij daje podobne rezultate, in sicer ugotavljajo, da se motnja $\mathrm{v}$ večini primerov prenaša genetsko oz. medgeneracijsko. $\mathrm{V}$ ostalih primerih pa je ADHD posledica pridobljene poškodbe ali bolezni možganov (npr. posledice izpostavljenosti nevrotoksinom, infekcije), motnje v duševnem razvoju, izpostavljenost psihoaktivnim substancam $\mathrm{v}$ času nosečnosti ter nizke porodne teže (American Psychiatric Association, 2000; Biederman idr., 1986; Biederman idr., 1990; Mick, Biederman, Faraone, Sayer in Kleinman, 2002; Satterfield, Cantwell, Lesser in Posodin, 1972; Tomori, 1999). Biederman idr. (1986) ugotavljajo, da se ADHD pri otrocih in mladostnikih moškega spola pojavlja v 31,5 $\%$ pri sorodnikih prve stopnje, v primerjavi s kontrolno skupino, kjer se je ADHD pojavil le pri 5,7 \% sorodnikov prve stopnje. Ocenjujejo, da se ADHD podeduje v 70 do 90 \% (Levy, Hay, McStephen, Wood in Waldman, 1997).

Precej raziskav se je osredotočalo na nevrobiološki funkciji dezinhibicije in disregulacije. Te funkcije se nahajajo $\mathrm{v}$ strukturah frontalnega korteksa, motnja ADHD pa naj bi bila rezultat zmanjšanega delovanja »vedenjskega inhibicijskega sistema« (Barkley, 1997; Quay, 1997). Slikanje možganov z magnetno resonanco je pokazalo, da imajo osebe z ADHD zmanjšan obseg korpus kalozuma (Baumgardner idr., 1996; Giedd idr., 1994), desnega frontalnega lobusa (Filipek idr., 1997; Giedd idr., 1994), bazalnih ganglijev (Rubia idr., 1999) in manjšo skupno prostornino možganov, še posebej malih možganov (Castellanos idr., 1996). Ta odkritja nakazujejo, da je za ADHD značilno moteno delovanje malih možganov, frontalnega lobusa in striatuma. SPECT (single photon emission computer tomography) in PET (pozitronska emisijska tomografija) študije ravno tako kažejo zmanjšan pretok krvi preko frontalnega lobusa in caudate nucleus (Mostofsky, Reiss, Lockhart in Denckla, 1998), pa tudi nižji metabolizem glukoze v premotornem korteksu in v superiornem prefrontalnem korteksu, ki sta zadolžena za funkciji pozornosti in motorične aktivnosti (Zametkin idr., 1990). Motnje v prenosu in prisotnosti dopamina $\mathrm{v}$ prefrontalnem območju centralnega živčnega sistema (CŽS) zaustavljajo krvni obtok in metabolizem, ki zmanjšujeta kontrolo iz spodnjih struktur možganov in lahko potencialno povzročata simptome ADHD (Cockburn in Holroyd, 2010; Tomori, 1999).

Etiologija motnje ADHD je manj jasna na področju medosebnih odnosov in drugih okoljsko-socialnih dejavnikov (Johnston in Mash, 2001). Čeprav lahko motnja ADHD temelji na bionevroloških faktorjih, ne obstaja ločena od socialne okolice. Vsak družinski sistem se mora prilagoditi na posameznika z motnjo, saj mora vzdrževati družinsko stabilnost in uravnoteženost. Potrebne prilagoditve so navadno zelo obsežne in vplivajo na vse družinske člane in vloge: starše/partnerja, sorojence in ostale sorodnike. Vzdrževanje teh prilagoditev skupaj s stresom in frustracijo, ki ju družinski člani doživljajo, vpliva tudi na mnoge druge sisteme ter se prenaša medgeneracijsko (Everett in Everett, 1999).

ADHD je bolj pogosta pri prvostopenjskih bioloških sorodnikih otrok $\mathrm{z}$ motnjo (American Psychiatric Association, 2000). Nekateri menijo, da se medgeneracijski prenos pojavi predvsem zaradi vztrajanja simptomatike ADHD iz otroštva v odraslost (Barkley, 1998a). Tako imajo mnogi otroci z ADHD tudi starše z ADHD, kar družinsko dinamiko nedvomno dodatno otežuje in povečuje kompleksnost odnosov (Eakin idr., 2004; Everett in Everett, 1999; Harvey, Danforth, Eberhardt McKee, Ulaszek in Friedman, 2003; Takeda idr., 2010). Četudi starši motnje nimajo, vseeno vedenjske težave otrok povezane z ADHD predstavljajo veliko breme, stres in znižujejo kakovost življenja (Lange idr., 2005), pa tudi otežujejo interakcijo starš-otrok (Lindahl, 1998).

Starši otrok z ADHD izvajajo bolj prisilne in odklonilne vzgojne stile ter imajo občutek, da jim primanjkuje starševskih sposobnosti (Kaplan, Crawford, Fisher in Dewey, 1998). So bolj nagnjeni k neodobravanju, imajo bolj stroge zahteve ter so bolj kritični do svojih otrok $\mathrm{v}$ primerjavi s starši otrok, ki nimajo ADHD. 
Ugotovljeno je, da družine $\mathrm{z}$ otroci z ADHD slabše delujejo na različnih področjih, za njih je značilno več konfliktov med partnerjema, nizka povezanost med člani, slabša komunikacija in zmožnosti reševanja problemov, zmanjšana organiziranost, odsotnost čustvene odzivnosti, topline in vključenosti staršev, večje zavračanje otrok, šibko postavljene zahteve in pravila ter nestalne vloge (Biederman idr., 1995; Edwards, Barkley, Laneri, Fletcher in Metevia, 2001; Kaplan idr., 1998; Lange idr., 2005; Lifford, Harold in Thapar, 2008; Minde idr., 2003; Pressman idr., 2006; Schroeder in Kelley, 2009; Tripp, Schaughency, Langlands in Mouat, 2007). J. Kendall (1999) je v svoji študiji podala izsledke mnenj sorojencev otroka z ADHD, ki se počutijo žrtve zaradi agresivnih vedenj sorojenca z ADHD, velikokrat pa so s strani staršev postavljeni v vlogo skrbnika ter imajo občutke obžalovanja in izgube. Na podlagi pregleda literature, ki se osredotoča na stile navezanosti v družinah, kjer je otrok z ADHD oz. pri otrocih z ADHD lahko povzamemo, da se pri članih družine oz. pri samem otroku z motnjo večinoma pojavlja nevaren način navezanosti (Clarke, Ungerer, Chahoud, Johnson in Stiefel, 2002; Dallos in Smart, 2011; Finzi-Dottan, Manor in Tyano, 2006) predvsem v obliki dezorganiziranega tipa (Bohlin, Eninger, Brocki in Thorell, 2012; Goldwyn, Stanley, Smith in Green, 2000; Green, Stanley in Peters, 2007).

\section{Zdravljenje ADHD pri otrocih}

Strokovna obravnava otrok $\mathrm{z}$ motnjo ADHD mora biti celovita in usklajena, hkrati pa občutljivo prilagojena posebnostim vsakega otroka ter usmerjena $v$ preprečevanje razvoja sekundarnih posledic osnovnih motenj (Tomori, 1999). Za zdravljenje ADHD pri otrocih se uporablja medikamentozno terapijo, razvili pa so tudi različne pristope, ki temeljijo na že uveljavljenih terapevtskih modalitetah in treningih. Sprva so bile obravnave usmerjene bolj na otroka $\mathrm{z}$ motnjo, sčasoma pa so vedno bolj vključevali družinske člane, ki, četudi morda nimajo vpliva na pojav motnje pri otroku, skoraj vedno občutijo posledice in spremembo dinamike v družini.

Stimulansi CŽS (Ritalin, Dexedrin, Cylert) so najbolj pogosto uporabljena psihotropna snov za zdravljenje simptomov ADHD (DuPaul, Barkley in Connor, 1998; Tomori, 1999), v manjši meri pa tudi antidepresivi (Conners, Casat, Gualtieri in Weller, 1996; Daly in Wilens, 1998). Empirični rezultati dosledno kažejo na njihovo učinkovitost, saj se izboljša otrokova vedenjska, šolska, socialna in čustvena problematika, in sicer v 50 do $95 \%$ primerov. Njihova učinkovitost je nižja v primerih pridruženih duševnih motenj. V vsakem primeru je poleg medikamentozne potrebna še druga vrsta terapije, učinek vseh pa se lahko potencira. Kljub precejšnjemu raziskovanju pa ostaja uporaba stimulansov kontroverzna, tako z vidika stroke kot javnosti (DuPaul idr., 1998; Tomori, 1999), predvsem zaradi možnih negativnih stranskih učinkov, kot so npr. nespečnost, glavoboli, izguba apetita (Pliszka, 2007), zvišanje srčnega utripa, krvnega pritiska
(Rapport in Moffitt, 2002), »privzdignjeno« počutje (DuPaul, Anastopoulos, Kwasnik, Barkley in McMurray, 1996), motnje spanja (Stein idr., 2003), produktivna psihopatološka simptomatika (halucinacije, manija) (Biederman, Newcorn in Sprich, 1991) in večja verjetnost kasnejše zlorabe psihoaktivnih substanc (Biederman idr., 2008; Lambert in Hartsough, 1998; Volkow in Swanson, 2008). Kljub splošni učinkovitosti psihostimulansov pri zdravljenju ADHD je potrebno opozoriti, da od $20 \%$ do $30 \%$ otrok ob uporabi teh zdravil ne kaže nobenega izboljšanja ali celo kaže poslabšanje vedenja. Raziskav, ki bi preverjale dolgotrajno učinkovitost medikamentov za zdravljenje ADHD, ni bilo izvedenih predvsem zaradi etične nesprejemljivosti, saj bi kontrolna skupina udeležencev morala uživati placebo od otroštva do odraslosti (Santosh in Taylor, 2000). Nekaj raziskav je ocenjevalo učinkovitost $\mathrm{v}$ obdobju daljšem od enega leta in ugotovilo, da pride do znižanja simptomatike ADHD v domačem okolju (Gillberg idr., 1997; v Santosh in Taylor, 2000) in v šoli (MTA Cooperative Group, 1999).

Pri nevrofeedbacku gre za naučeno samouravnavanje možganske aktivnosti preko povratne zveze po načelu nagrajevanja. Klient dobi informacije o lastnih fizioloških procesih v možganih. Tako se postopno nauči uravnavati svojo možgansko aktivnost. Otroci morajo npr. doseči, da se predmeti na ekranu gibljejo hitreje, kateri od predmetov poveča itd. Nekateri protokoli predvidevajo nagradne točke po vsaki uspešni seansi, ki jih lahko otrok kasneje zamenja za konkretno nagrado (Holnthaner, 2008). Raziskave, izvedene na otrocih in mladostnikih z ADHD, ki so bili deležni določenega števila ur EEG feedbacka, so pri večini pokazale izboljšanje pozornosti, zmanjšanje impulzivnosti, izboljšano procesiranje informacij ter zmanjšanje theta aktivnosti (Fuchs, Birbaumer, Lutzenberger, Gruzelier in Kaiser, 2003; Lubar, Swartwood, Swartwood in O'Donnell, 1995; Rossiter in La Vaque, 1995). Nevrofeedback bi utegnil postati pomemben element obravnave otrok z ADHD v okviru širšega multimodalno zastavljenega pristopa, še zlasti pri otrocih staršev, ki se ne strinjajo z medikamentozno terapijo. Nezaželeni stranski učinki nevrofeedbacka zaenkrat niso znani. Občasno se preizkušanci pritožujejo nad glavoboli in utrujenostjo, ki pa sta verjetno posledici vzdrževanja pozornosti in $\mathrm{s}$ tem povezane mišične napetosti (Holnthaner, 2008).

Ker družinsko okolje $\mathrm{v}$ določeni meri prispeva in vzdržuje simptomatiko ADHD pri otroku, so se intervence sčasoma usmerile na vse ožje družinske člane, pa tudi člane širše družine. Pristop vodenja staršev se je izkazal za enega od najbolj učinkovitih za zmanjševanje agresivnega, neprimernega, antisocialnega in hiperaktivnega vedenja pri otrocih (Anastopoulos, Smith in Wien, 1998). Ta vrsta intervence jenajboljučinkovita primlajših otrocih v starosti od 3 do 10 let. Program je manj primeren za starše tistih otrok, ki poleg simptomov ADHD kažejo tudi simptome depresije, anksioznosti in drugih emocionalnih motenj, saj je potrebno najprej obravnavati in zdraviti slednje. Ravno tako je kontraindikacija prisotnost starševskega konflikta, duševnih motenj, diagnoze ADHD ali motenj v duševnem 
razvoju pri starših. Program vodenja staršev traja od 8 do 12 srečanj, temelji pa na vedenjsko-kognitivnih terapevtskih strategijah in psihoedukaciji. Terapevt na podlagi podatkov iz začetnega intervjuja in ostalih diagnostičnih postopkov starša izobrazi o možnih vzrokih za neprimerno vedenje njihovih otrok, ki lahko izhajajo iz otrokovih značilnosti (npr. stila temperamenta, obsega pozornosti, odzivnosti na dražljaje), značilnosti staršev in njihovega starševstva, medosebnih odnosov med starši in otrokom ter dejavnikov stresa. Terapevt starša spodbuja, da v svoji družini ugotovita možne vzroke otrokovega težavnega vedenja ter ju motivira, da razmišljata o možnih rešitvah. Nadalje sledi pomoč staršem, da na otroka pričnejo gledati v bolj pozitivni luči, kar dosežejo preko zmanjšanja ukazovalnosti in kritičnosti do otroka ter pogostejših pohval otrokovega primernega vedenja. Če zgoraj navedeni pristopi ne delujejo, se starše poduči o tehnikah žetoniranja, s čemer se otrok preko zunanje motivacije in nagrajevanja nauči primernega vedenja. Terapevt skuša prepoznati iracionalna prepričanja staršev (npr. »ta intervenca pri mojem otroku ne bo delovala «), saj lahko znižujejo uspešnost izvajanja vedenjskih tehnik v domačem okolju. V teh primerih je potrebno prepričanje obravnavati in preko razgovora ugotoviti, kakšne so realne možnosti, da se njuna prepričanja uresničijo. V najhujših primerih agresivnega in neprimernega vedenja otroka in ob neuspehu s prej navedenimi izvedenimi intervencami terapevt starše seznani z vedenjsko tehniko »time out«, ki tako kot tehnika žetoniranja deluje po principu instrumentalnega pogojevanja. Starša določita eno otrokovo nezaželeno vedenje in ob njegovem pojavljanju otroka pošljeta $\mathrm{v}$ izbran prostor $\mathrm{v}$ stanovanju, kjer mora počakati in biti tiho toliko minut, kakršna je njegova starost. Po pretečenem času se starša $\mathrm{z}$ otrokom pogovorita o neprimernem vedenju, zaradi česar je bila uporabljena opisana tehnika. Tehniko »time out« starša izvajata do ugasitve obravnavanega vedenja. Terapevt s starši razpravlja o uspehih in neuspehih dosedanjega treninga ter jih še naprej spodbuja $\mathrm{k}$ uporabi naučenih tehnik za obvladovanje otrokovega vedenja. Starši o tehnikah (npr. spremljanje vedenja, žetoniranje) poučijo tudi otrokovo učiteljico. Ob zaključku programa starši s terapevtom razpravljajo še o možnih težavah v prihodnosti, njihovih rešitvah, ovrednoti se potek programa, starši pa prejemejo usmeritve v druge obravnave, če je to potrebno. Po približno enem mesecu po zaključku programa sledi eno ali več srečanj za dodatno utrjevanje in spremljanje izidov izvedene intervence.

Za več družinskih pristopov (reševanje problemov in trening komunikacije, strukturalna družinska terapija ter obvladovanje otrokovega vedenja za starše) za obravnavo družinskih konfliktov z mladostnikom z ADHD avtorji ugotavljajo visoko učinkovitost (Barkley, Guevremont, Anastopoulos in Fletcher, 1992; Barkley, Edwards, Laneri, Fletcher in Metevia, 2001). Znižal se je nivo konfliktov, negativne komunikacije, izbruhov jeze, pozunanjanja in ponotranjanja težav, izboljšala se je šolska uspešnost ter zmanjšali materini simptomi depresije .
Družinska terapija za družine z otrokom z ADHD se razvija šele v zadnjem obdobju. Raziskovalci poročajo o njeni učinkovitosti, saj motnja ADHD pri otroku vpliva na dinamiko celotne družine, pogosto pa ima simptome tudi vsaj eden od staršev, kar dinamiko še bolj zaostri. Družinski sistem omogoča tudi bogastvo virov, ki so pri zdravljenju dobrodošli, saj lahko ustvari trajnejše spremembe, kot pa le individualna pomoč otroku z ADHD (Everett in Everett, 1999).

V družini $\mathrm{z}$ otrokom z ADHD se morajo zaradi otrokovih težav vsi člani truditi, da ustvarijo stabilno ravnotežje in se prilagoditi simptomom otrokove motnje. Družine tako skušajo vzdrževati homeostazo, stalen proces, s katerim si prizadevajo obstati v ravnotežju kljub nefunkcionalnim ali motečim dejavnikom. Nekatere družine imajo vire moči za povrnitev ravnotežja v starših oz. v hierarhični strukturi, druge pa vstopijo v terapevtski proces po nekajletnem kaosu $\mathrm{v}$ družini. Za obnovo razmejitev in porušene hierarhije $\mathrm{v}$ sistemu je potrebno poglobljeno analizirati podsisteme $\mathrm{v}$ družini ter meje med družinskim sistemom ter okolico in posameznimi podsistemi (Everett in Everett, 1999).

Povečan stres in večje spremembe v okolju vplivajo preko prenosa reakcij iz enega člana družine na vse člane družine. Velikokrat se simptomi nekih frustracij zberejo v enemu članu družine, ki ga imenujemo »grešni kozel«. Precej otrok z ADHD ima izkušnjo te vloge v svojih družinah. Otrokovo neprimerno vedenje zahteva čas, energijo in vire moči staršev, sorojencev, starih staršev, učiteljev, da se s spremembami spopadejo. Stalni odzivi družinskih članov zbujajo frustracijo in navsezadnje jezo, kar kmalu privede do etiketiranja otroka kot »problematičnega«, »lenega«, »zgubo« ali »bebca«. Dodeljeno vlogo in identiteto »grešnega kozla« v družini hitro "posvojijo« vsi člani, kot tudi učitelji in ostali. Navsezadnje je potrebno raziskati in zdraviti čustveno dinamiko v odnosih med člani družine (ožje in širše) (npr. občutki krivde, frustracije, negotov slog čustvenega medosebnega navezovanja, nepotešene čustvene potrebe itd.), ki se do neke mere prenaša medgeneracijsko skozi vzorce vedenj in čustvovanj (Everett in Everett, 1999). Lahko pa mu je ta vloga že prvenstveno dodeljena zaradi vzpostavljanja družinskega ravnovesja in težnje sistema $\mathrm{k}$ izogibanju bolečih vsebin in $\mathrm{k}$ nereševanju problemov. Avtorja še poudarjata, da je potrebno dinamiko valjenja krivde le na enega člana družine prekiniti, saj se šele potem lahko pozornost preusmeri na bolj globlje in temeljne probleme v družini.

Še preden se proces poteka družinske terapije prične, je potrebno zbrati začetne informacije o zgodovini simptomatike ADHD in ostale pomembne podatke o delovanju posameznih članov ter družine kot celote. Anamnezo podajo posebej starši in otrok z ADHD, upoštevajoč njegovo starost. Pomembno je raziskati možnosti simptomatike ADHD in drugih duševnih motenj pri ostalih članih družine, predvsem starših. Podatke terapevt pridobi tudi z opazovanjem interakcije predvsem med starši in otroci, kot tudi med ostalimi člani. Terapevt 
mora ves čas načrtovati svoje intervencije $\mathrm{z}$ namenom učvrstitve mej, $\mathrm{z}$ določevanjem podsistemov in interakcij med njimi ter uravnavati potek obravnave glede na značilnosti članov in družine kot celote. V prvih korakih psihoedukacija in psihoterapija s starši igrata pomembno vlogo, saj se s tem preusmeri pozornost $\mathrm{z}$ otroka $\mathrm{z}$ ADHD na celoten sistem. Utrditi je potrebno podsistem staršev in s tem hkrati popraviti ali na novo postaviti porušeno hierarhijo, ki daje sistemu varnost. Bližino med staršema obnovimo $\mathrm{z}$ izboljšanjem komunikacije in medsebojne podpore pri vzgajanju otrok. Podaljšano zdravljenje družine z otrokom z ADHD je ponavadi potrebno, kadar imata starša omejene vire učenja, čustvovanja, kjer je prisotne več psihopatologije in kjer $\mathrm{v}$ kratkem času ne moreta narediti večjih sistemskih sprememb. Vendar je vseeno nujno čim bolj skrajšati srečanja $\mathrm{z}$ otrokom, saj $\mathrm{v}$ nasprotnem primeru le utrjujemo njegovo podobo kot »neustreznega«. Terapevtska srečanja večinoma potekajo s starši in otrokom z ADHD, ko pa se dinamika med njimi izboljša, so v obravnavo povabljeni sorojenci in ostali člani širše družine, ki imajo pomembno vlogo za družino z otrokom z ADHD (Everett in Everett, 1999).

\section{Relacijska družinska terapija kot metoda za zdravljenje otrok z ADHD ter njihovih družin}

Relacijski družinski model (RDT) zajema dosedanja področja relacijsko usmerjenih avtorjev in jih integrira na svojstven način (združeni principi objekt relacijskih teorij, self psihologije in interpersonalne psihoanalize), v svojem pojmovanju delovanja družin pa vključuje tudi osnovne zakonitosti in principe sistemsko-kibernetske teorije (Gostečnik, 2004). Posameznika se v tem modelu vedno razume kot del celotne družine, ki ji pripada oz. v kateri je odraščal, odnosi pa so tisti bistveni dejavniki, ki vplivajo na razvoj posameznikove psihične strukture. To je postala splošno sprejeta psihološka paradigma, na osnovi katere sodobni avtorji raziskujejo dinamiko družine ter vzroke duševnih motenj.

Pokazalo se je, da za medsebojne odnose med posameznikom in njegovim relacijskim kontekstom velja vzajemna krožna vzročnost (Umbarger, 1983; v Gostečnik, 2004), člani družine namreč drug na drugega vplivajo, se medsebojno pogojujejo in vzajemno drug v drugem vzbujajo in ustvarjajo določene miselne, čustvene in vedenjske oblike medosebnih odnosov, ki oblikujejo način uravnavanja afekta $\mathrm{v}$ vsaki družini. Ne gre torej samo za določenega člana družine, konkretno otroka z ADHD, ki povzroči določen odziv v ostalih članih, ampak tudi ostali člani na svojski način vplivajo na vedenje, razmišljanje in doživljanje tega posameznega člana. Družina je tudi celovit sistem, kar pomeni, da je vedno večji in močnejši od njegovih posameznih delov oz. podsistemov. Sistem družine je v tem pogledu organsko-socialno-afektivni sistem, ki ga v njegovem temelju tvori skupek odnosov, ki so hierarhično organizirani in medsebojno odvisni. Vsaka družina je sestavljena iz podsistemov, ki na osnovi pravil in rutin sestavljajo ter organizirajo sistem v celoto. Temeljna podsistema $\mathrm{v}$ družini sta starševski in otroški, obenem pa tudi vsak član družine predstavlja svoj podsistem. Ti podsistemi so $\mathrm{V}$ nenehnih dinamičnih odnosih drug $\mathrm{z}$ drugim in so organizirani okrog dejavnosti ter afektov, ki so kritičnega pomena za preživetje celotnega sistema družine (Umbarger, 1983; v Gostečnik, 2004). Vsaka družina ima svoja pravila, ki vodijo in urejajo družinski sistem ter vzdržujejo sistem v ravnovesju ter sistemski homeostazi (Bradshaw, 1996). Četudi se ADHD pri otroku pojavi neodvisno od dogajanj $v$ družini in širši socialni mreži, vseeno otrokove težave vzajemno vplivajo na ostale družinske člane in lahko simptomatiko še dodatno spodbujajo (American Psychiatric Association, 2000; Everett in Everett, 1999; Harvey idr., 2003; Takeda idr., 2010). Pri ocenjevanju in zdravljenju ADHD je potrebna analiza podsistemov v družini, ki definirajo tako hierarhijo kot članstvo v vsaki skupini. Predpostavljena hierarhija $\mathrm{v}$ družini obsega starševski podsistem, ki ima moč odločanja, podsistem starš-otrok, ki definira medosebne vloge ter avtoriteto med starši in otroci, podsistem sorojencev, $\mathrm{v}$ katerem se ponavadi nahaja otrok $\mathrm{z}$ diagnozo ADHD in medgeneracijski sistem, ki definira ostale pomembne akterje $\mathrm{v}$ družinskem sistemu. Pomembno je razumeti, kako otroka z ADHD vidijo tako starši kot sorojenci, saj v skladu s stanjem lahko planiramo bolj učinkovite terapevtske intervence (Everett in Everett, 1999). V družinah brez hierarhije, kjer starši ne zmorejo sprejeti odgovornosti za družino, gre torej za zelo nezdrave in boleče odnose ter zelo razbolel proces, ki zaradi svoje nefunkcionalne strukture nenehno posreduje nove intrapsihične ali interpersonalne razdiralne vsebine v otroke (Gostečnik, 2004).

Razumevanje zapletenega družinskega sistema, kjer vsak član družine igra svojo vlogo, model RDT razlaga kot rezultat procesov kompulzivnega ponavljanja (mehanizem prisilnega ponavljanja naučenih načinov delovanja) ter projekcijsko-introjekcijske identifikacije (mehanizem prenosačustevizene osebena drugo) in produkt specifičnih potreb družine kot sistema. Mehanizma kompulzivnega ponavljanja ter projekcijsko-introjekcijske indentifikacije omogočata prenos temeljnega afekta in ostalih vsebin iz posameznika na medosebno in sistemsko raven ter $\mathrm{v}$ obratni smeri. Tako je vsak od članov družine nosilec zelo specifičnih čustev, mišljenj in vedenj, značilnosti medosebnega delovanja pa se prenašajo tudi iz generacije v generacijo (Gostečnik, 2004).

Glede na ugotovitve drugih raziskovalcev o visoki prisotnosti motnje ADHD pri starših otrok z ADHD lahko predvidevamo, da v teh družinah vsaj delno prihaja do prenosa določenih vsebin simptomatike ADHD iz staršev na otroke. Simptomi hiperaktivnosti sicer v odraslosti ponavadi izzvenijo oz. se pojavljajo bolj $\mathrm{v}$ obliki notranje nemirnosti, razdražljivosti, reaktivnosti in nepotrpežljivosti. Bolj pogosto vztrajajo simptomi zmanjšane pozornosti in občasno impulzivnosti, kjer se slednja kaže v prenagljenih nakupih, zadolženosti, prehitrih odločitvah in nepremišljenih reakcijah oz. izjavah, ki so lahko boleče in polne kriticizma, s čemer 
dajejo te osebe vtis infantilnosti in nezrelosti, z njimi pa se je nemogoče dogovoriti o aktivnostih in odločitvah (Everett in Everett, 1999; Hart, Lahey, Loeber, Applegate in Frick, 1995; Resnick, 2005; Wilens, Biederman in Spencer, 2002). Možno je, da otroci teh staršev že v zgodnjem otroštvu preko mehanizmov projekcijsko-introjekcijske identifikacije in kompulzivnega ponavljanja ponotranjijo njihov način delovanja, ki lahko kasneje, sploh če je pri otrocih prisotna še biološka in/ali psihosocialna ranljivost na drugih področjih, izbruhne v obliki motnje ADHD z večino pripadajočih simptomov. Te procese je potrebno ubesediti in skupaj s člani družine poskušati najti različne rešitve, ki bi pripomogle $\mathrm{k}$ izboljšanju medosebnih odnosov.

Med staršema, kjer ima vsaj eden od njiju bolj ali manj izražene simptome ADHD, prihaja do večje mere konfliktov na skoraj vseh področjih (komunikacija, intimnost, skrb zase, seksualnost, prosti čas za hobije in druženje s prijatelji, finance in njihovo upravljanje, odgovornost $\mathrm{v}$ vzgoji, gospodinjska opravila in odgovornosti, zaposlitev in kariera ter zloraba psihoaktivnih substanc). Konflikt je pogosto prisoten že od začetka razmerja, ki se skozi čas poglablja in postaja vedno bolj intenziven, še posebej pa se stanje poslabša v času nosečnosti in po rojstvu prvega otroka. Ta dogodek je tako intenziven in zahteva precejšnje spremembe $v$ odnosu, sprejemanja odgovornosti in vzorcih vedenja, ki pa jih čustveno manj zrela in patološko odvisna partnerja z manj učinkovito komunikacijo in nevarno navezanostjo le stežka zmoreta (Eakin idr., 2004; Everett in Everett, 1999; Minde idr., 2003). Osebam z ADHD ponavadi primanjkujejo socialne spretnosti in zmožnost uvida, da bi opazili ali se odzvali na prisotne težave v partnerskem odnosu, k čemur prispeva zaradi pomanjkljive pozornosti tudi sama motnja ADHD. Njihovi partnerji pogosto pričnejo kazati ekstremna vedenja (npr. kričanje, razbijanje stvari), da pritegnejo njihovo pozornost, a jim to ponavadi ne uspe. Partner brez ADHD je tako obsojen na vlogo »preganjalca« oz. »približevalca« in daje stalne pobude za interakcijo ter skuša pridobiti odzive in povratne informacije od partnerja. Pri tem je ponavadi manj uspešen. Čez čas se zaradi omenjene dinamike partner brez ADHD počuti manjvrednega ali neprivlačnega za partnerja, postane jezen, frustriran, goji zamero, med njima pa se vzpostavi distanca, ki lahko rezultira v razvezi ali duševnih motnjah (depresija, obupanost itd.). Opaziti je tudi vztrajajoč občutek krivde tako s strani staršev otroka z ADHD zaradi »napak« v vzgoji, kot otroka s težavami, ker ne zmore zadostiti zahtevam svojih staršev ali pa se ne zmorejo kontrolirati, so neumni itd. Sorojencem je žal za težave brata ali sestre z ADHD, se počutijo frustrirane zaradi prizadevanj njihovih staršev, ko pa odrastejo, pa si pogosto želijo, da bi bili do svojih sorojencev bolj tolerantni in sočutni. Odrasli z ADHD, ki so jim postavili diagnozo šele v odraslosti, se pogosto opravičujejo svojim sedanjim družinam, da si niso že prej priskrbeli pomoči, ravno tako pa obžalujejo svoje vedenje kot otrok v odnosu do staršev. Občutek krivde v družini je pravzaprav odraz neuspeha, ki ga doživljajo in izražajo vsi člani družine.
V analizo je smiselno vključiti tudi prepoznavanje meja med družinskim sistemom ter okolico in posameznimi podsistemi, saj služijo definiranju in zaščiti sistema. Funkcionalne družine imajo večinoma bolj odprte in fleksibilne meje, ki kažejo na izmenjavo z okolico in spremenljivost oz. prilagajanje na situacijo, v kateri se sistem znajde (Everett in Everett, 1999). Še posebej $\mathrm{v}$ primerih pojava težav $\mathrm{v}$ družini (npr. težave otrok $\mathrm{z}$ ADHD), pa lahko pride do povečane togosti v razmejitvah tako intrapsihično, med posamezniki, podsistemi kot med družino in okolico. Tako so ključni družinski procesi lahko ovirani; ne bo mogoče pričakovati progresivnega ločevanja, opredelitve in določitve funkcij posameznega člana družine; njegova intrapsihična struktura se ne bo zdravo razvila, saj ne bo imel občutka, da pripada določenemu podsistemu $\mathrm{v}$ celotnem sistemu. Brez teh sistemskih razmejitev bo za posamezne člane skoraj nemogoče razviti sposobnost ustvarjanja in ohranjanja plastičnosti in sposobnosti prilagoditve $\mathrm{V}$ soočenju $\mathrm{Z}$ okoljem. Brez te prilagoditve bo sistem vedno v težavah, njegovi posamezni deli pa bodo kazali najrazličnejše simptome. Razmejitve obenem urejajo tudi tok informacij in energijo, ki so potrebna za vsak živ sistem, da ohranja harmonično ravnotežje s kontekstom okolja (Bradshaw, 1996).

Razmejitve tudi dovoljujejo, da določene informacije prosto prehajajo in se širijo v družinskem sistemu, medtem ko druge informacije nimajo vstopa v družino (Gostečnik, 2004). Informacije in energija se v sistemu prenašajo ter uravnavajo s pomočjo mehanizma, ki mu kibernetska teorija pravi povratna zveza ali feedback zanka, po katerih $\mathrm{v}$ družini krožijo čustva in prehajajo med podsistemi (Umbarger, 1983; v Gostečnik, 2004). Gre za zelo močne afektivne komunikacijske poti, ki vodijo z intrapsihične preko interpersonalne do sistemske ravni doživljanja ter se vedno znova vračajo nazaj na intrapsihično raven, s čimer ustvarjajo temeljno čustveno dinamiko celotnega sistema. Vsaka sprememba lahko zamaje družinsko stabilnost ali celo preobrne utečeni ritem družinskih odnosov. Vsi se morajo prilagoditi na spremembe, vzpostaviti morajo novo sistemsko ravnovesje, ki šele omogoča ponovno homeostazo (Gostečnik, 2004). Živ sistem mora rasti in se razvijati, vendar na način, ki omogoča, da hkrati ostaja stabilen. Spremembe in razvoj se bodo torej udejanjale na način in po stopnjah, ki bodo omogočale ohranjanje čuta, da gre še vedno za isti družinski sistem (Umbarger, 1983; v Gostečnik, 2004).

RDT v svoj model vključuje še pojem afektivnega psihičnega konstrukta, ki je kompleksen obrambni mehanizem in pokrivalo temeljnega afekta, ki si ga posameznik ustvari, da ga zavaruje pred nadaljnjo ranljivostjo. Posameznik odcepi, potlači, zanika ali disociira določene boleče, travmatične psihične vsebine in si namesto njih ustvari afektivne psihične konstrukte ter $\mathrm{s}$ tem zavaruje pred nadaljnjimi vdori bolečih vsebin. S tem pa se zgodba ne zaključi, saj te vsebine nezavedno delujejo ter se preko projekcijsko-introjekcijske identifikacije prenašajo na druge osebe (npr. izenega partnerja na drugega in obratno, iz staršev na otroke itd.) in ob njih prebujajo 
(Gostečnik, 2004). Afektivni psihični konstrukt bi se lahko v konkretnem primeru kazal v obliki motnje ADHD pri otroku in hkrati oteževal reševanje drugih, globljih in težjih konfliktov, stisk, bolečin, ki so nastali med staršema oz. se prenašajo med več generacijami in tako vzdržuje celoten družinski sistem $\mathrm{v}$ njegovi nefunkcionalnosti. Pojav afektivnega psihičnega konstrukta na svoj način razlagata tudi Everett in Everett (1999), uporabljata pa izraz pretirane navezanosti oz. vertikalne lojalnosti, kar pojasnjujeta $z$ nerazrešenimi čustvenimi potrebami in identiteto "grešnega kozla«. Oseba z ADHD, ki je doživela veliko frustracij, nepotešenih čustvenih potreb, ima bolj negativno samopodobo in se nasploh počuti manj ustreznega, ostaja v bližini svoje primarne družine, če že ne fizični, pa čustveni. Vertikalna lojalnost se ponavadi tudi prenaša medgeneracijsko skozi vzorce vedenj in čustvovanj. Za te posameznike pa so posledično značilne tudi manj intenzivne vezi in pomanjkljiva čustvena razpoložljivost v partnerskem odnosu.

Duševne motnje, kakor tudi dinamika funkcionalne družine, dobivajo $\mathrm{v}$ relacijskem družinskem modelu in razmišljanju čisto drugačno podobo. Pacient oz. »grešni kozel«jevtemprimerunajvečkratsamosimptomoz.zunanji izraz družinske patologije, njene čustvene vznemirjenosti in razrvanosti, ki se prek mehanizma projekcijske identifikacije in kompulzivnega ponavljanja prenaša na določenega člana družine. Simptomatični posameznik vedno predstavlja kompromis med družinskimi cilji in cilji prejšnjih generacij ter išče ravnotežje oz. novo, sprejemljivejšo družinsko homeostazo in obljublja bolj funkcionalno delovanje celotne družine. Te oblike čutenja, mišljenja in delovanja problematični posameznik vedno znova ponavlja v svojem nadaljnjem življenju, saj zanj pomenijo primarni odnos, ki je konstitutivni del njihove psihične zgradbe in zato tudi predstavlja pripadnost družinskemu sistemu, za katerega nezavedno čuti, da brez njega ne bi mogel preživeti (Gostečnik, 2004).

V okviru relacijske družinske terapije bi bila za družine s članom $\mathrm{z}$ ADHD zaradi nakazanega bolj nevarnega načina navezovanja smiselna najprej analiza različnih načinov navezanosti (Erzar in Kompan Erzar, 2011), zatem pa osredotočanje na procese navezovanja $\mathrm{v}$ sedanji in izvorni družini ter njihovo ovrednotenje $\mathrm{s}$ stališča otrokovih potreb, na dejanske otrokove izkušnje ločitve, izgub, zlorab, prikrajšanosti in zanemarjanja, opazljive poteze otrokovega vedenja v odnosu do staršev, zlasti čustvene plati teh odnosov in tega vedenja v dejanski terapevtski situaciji (tu in zdaj).

\section{Zaključek}

Zaradi kompleksnosti težav, ki jih motnja ADHD pri otroku povzroči v družinah, je za njihovo uspešno obravnavo potrebno osredotočanje na doživljanje vsakega posameznega člana družine, na njihove medosebne odnose, njihovo čustveno dinamiko, preveriti in obravnavati pa je potrebno tudi medgeneracijske prenose tako afektivnih kot mentalnih vsebin, kar so pomembne sestavine relacijskega družinskega modela. Vsaka sprememba v sistemu ali podsistemih ima velik vpliv na celoten sistem, ki se spreminja ali pa vzdržuje sistemsko ravnotežje. Tako lahko zaključimo, da je relacijska družinska terapija skupaj z ostalimi načini medicinskega in psihološkega oz. psihoterapevtskega zdravljenja uporabna kot metoda kompleksne obravnave otrok $\mathrm{z}$ ADHD in njihovih družin.

\section{Zahvala}

Zahvaljujem se recenzentu/-ki za predlagane strokovne popravke, ki so mi pomagali pri oblikovanju bolj kvalitetnega prispevka.

\section{Literatura}

American Psychiatric Association. (2000). Diagnostic and statistical manual of mental disorders: DSM-IVTR (4th ed., text rev.). Washington, DC, ZDA: Avtor.

Anastopoulos, A., Smith, J. M. in Wien, E. E. (1998). Counselling and training parents. V R. A. Barkley (ur.), Attention-deficit hyperactivity disorder: A handbook for diagnosis and treatment (str. 373-393). New York, NY, ZDA: The Guilford Press.

Barkley, R. A. (1997). Behavioral inhibition, sustained attention, and executive functions: Constructing a unifying theory of ADHD. Psychological Bulletin, 121, 65-94.

Barkley, R. A. (1998a). History. V R. A. Barkley (ur.), Attention-deficit hyperactivity disorder: A handbook for diagnosis and treatment (str. 1-22). New York, NY, ZDA: The Guilford Press.

Barkley, R. A. (1998b). Primary symptoms, diagnostic criteria, prevalence, and gender differences. V R. A. Barkley (ur.), Attention-deficit hyperactivity disorder: A handbook for diagnosis and treatment (str. 23-35). New York, NY, ZDA: The Guilford Press.

Barkley, R. A. (1998c). Developmental course, adult outcome, and clinic-referred ADHD adults. V R. A. Barkley (ur.), Attention-deficit hyperactivity disorder: a handbook for diagnosis and treatment (str. 112126). New York, NY, ZDA: The Guilford Press.

Barkley, R. A., DuPaul, G. J. in McMurray, M. B. (1990). Comprehensive evaluation of Attention deficit disorder with and without hyperactivity as defined by research criteria. Journal of Consulting and Clinical Psychology, 58, 775-789.

Barkley, R. A., Guevremont, D. C., Anastopoulos, A. D. in Fletcher, K. E. (1992). A comparison of three family therapy programs for treating family conflicts in adolescents with attention-deficit hyperactivity disorder. Journal of Consulting and Clinical Psychology, 60, 450-462.

Barkley, R. A., Edwards, G., Laneri, M., Fletcher, K. in Metevia, L. (2001). The efficacy of problem-solving communication training alone, behavior management training alone, and their combination for parent- 
adolescent conflict in teenagers with ADHD and ODD. Journal of Consulting and Clinical Psychology, 69, 926-941.

Baumgardner, T. L., Singer, H. S., Denckla, M. B., Rubin, M. A., Abrams, M. T., Colli, M. J. in Reiss, A. L. (1996). Corpus callosum morphology in children with Tourette syndrome and attention deficit hyperactivity disorder. Neurology, 47, 477-482.

Biederman, J., Munir, K., Knee, D., Habelow, W., Armentano, M., Autor, S., Hoge, S. K. in Waternaux, C. (1986). A family study of patients with attention deficit disorder and normal controls. Journal of Psychiatric Research, 20, 263-274.

Biederman, J., Faraone, S. V., Keenan, K., Knee, D. in Tsuang, M. T. (1990). Family-genetic and psychosocial risk factors in DSM-III attention deficit disorder. Journal of the American Academy of Child \& Adolescent Psychiatry, 29, 526-533.

Biederman, J., Newcorn, J. in Sprich, S. (1991). Comorbidity of attention deficit hyperactivity disorder with conduct, depressive, anxiety, and other disorders. The American Journal of Psychiatry, 148, 564-577.

Biederman, J., Milberger, S., Faraone, S. V., Kiely, K., Guite, J., Mick, E., Ablon, J. S., Warburton, R. in Reed, E. D. (1995). Impact of adversity on functioning and comorbidity in children with attention-deficit hyperactivity disorder. Journal of the American Academy of Child \& Adolescent Psychiatry, 34, 1495-1503.

Biederman, J., Monuteaux, M. C., Spencer, T., Wilens, T. E., MacPherson, H. A. in Faraone, S. V. (2008). Stimulant therapy and risk for subsequent substance use disorders in male adults with ADHD: A naturalistic controlled 10-year follow-up study. The American Journal of Psychiatry, 165, 597-603.

Bohlin, G., Eninger, L., Brocki, K. C. in Thorell, L. B. (2012). Disorganized attachment and inhibitory capacity: Predicting externalizing problem behaviors. Journal of Abnormal Child Psychology: An Official Publication of the International Society for Research in Child and Adolescent Psychopathology, 40, 449-458.

Bradshaw, J. (1996). Bradshaw on: The family. Deerfield Beach, FL, ZDA: Health Communications.

Brehaut, J. C., Miller, A., Raina, P. in McGrail, K. M. (2002). Childhood behavior disorders and injuries among children and youth: A population-based study. Pediatrics, 111, 262-269.

Castellanos, F. X., Giedd, J. N., Marsh, W. L., Hamburger, S. D., Vaituzis, A. C., Dickstein, D. P., Sarfatti, S. E., Vauss, Y. C., Snell, J. W., Lange, N., Kayser, D., Krain, A. L., Ritchie, G. F., Rajapakse, J. C. in Rapoport, J. L. (1996). Quantitative brain magnetic resonance imaging in attention-deficit hyperactivity disorder. Archives of General Psychiatry, 53, 607-616.

Clarke, L., Ungerer, J., Chahoud, K., Johnson, S. in Stiefel, I. (2002). Attention deficit hyperactivity disorder is associated with attachment insecurity. Clinical Child Psychology and Psychiatry, 7, 179-198.
Cockburn, J. in Holroyd, C. B. (2010). Focus on the positive: Computational simulations implicate asymmetrical reward prediction error signals in childhood attention-deficit/hyperactivity disorder. Brain Research, 1365, 18-34.

Conners, C. K., Casat, C. D., Gualtieri, C. T. in Weller, E. (1996). Bupropion hydrochloride in attention deficit disorder with hyperactivity. Journal of the American Academy of Child \& Adolescent Psychiatry, 35, 1314-1321.

Dallos, R. in Smart, C. (2011). An exploration of family dynamics and attachment strategies in a family with ADHD/conduct problems. Clinical Child Psychology and Psychiatry, 16, 535-550.

Daly, J. M. in Wilens, T. (1998). The use of tricyclics antidepressants in children and adolescents. Pediatric Clinics of North America, 45, 1123-1135.

DiScala, C., Lescohier, I., Barthel, M. in Li, G. (1998). Injuries to children with attention deficit hyperactivity disorder. Pediatrics, 102, 1415-1421.

DuPaul, G. J., Anastopoulos, A. D., Kwasnik, D., Barkley, R. A. in McMurray, M. B. (1996). Methylphenidate effects on children with attention deficit hyperactivity disorder: Self-report of symptoms, side-effects, and self-esteem. Journal of Attention Disorders, 1, 3-15.

DuPaul, G. J., Barkley, R. A. in Connor, D. F. (1998). Stimulants. V R. A. Barkley (ur.), Attention-deficit hyperactivity disorder: A handbook for diagnosis and treatment (str. 510-551). New York, NY, ZDA: The Guilford Press.

Eakin, L., Minde, K., Hechtman, L., Ochs, E., Krane, E., Bouffard, R., Greenfield, B. in Looper, K. (2004). The marital and family functioning of adults with ADHD and their spouses. Journal of Attention Disorders, 8 , $1-10$.

Edwards, G., Barkley, R. A., Laneri, M., Fletcher, K. in Metevia, L. (2001). Parent-adolescent conflict in teenagers with ADHD and ODD. Journal of Abnormal Child Psychology: An Official Publication of the International Society for Research in Child and Adolescent Psychopathology, 29, 557-572.

Erzar, T. in Kompan Erzar, K. (2011). Teorija navezanosti. Celje, SLO: Celjska Mohorjeva družba, Društvo Mohorjeva družba.

Everett, A. C. in Everett, S. V. (1999). Family therapy for ADHD: Treating children, adolescents, and adults. New York, NY, ZDA: The Guilford Press.

Faraone, S. V., Biederman, J., Lehman, B. K., Keenan, K., Norman, D., Seidman, L. J., ... Chen, W. J. (1993). Evidence for the independent familial transmission of attention deficit hyperactivity disorder and learning disabilities: Results from a family genetic study. The American Journal of Psychiatry, 150, 891-895.

Filipek, P. A., Semrud-Clikemann, M., Steingard, R. J., Renshaw, P. F., Kennedy D. N. in Biederman, J. (1997). Volumetric MRI analysis comparing subjects having attention-deficit hyperactivity disorder with normal controls. Neurology, 48, 589-601. 
Finzi-Dottan, R., Manor, I. in Tyano, S. (2006). ADHD, temperament, and parental style as predictors of the child's attachment patterns. Child Psychiatry and Human Development, 37, 103-114.

Fischer, M., Barkley, R. A., Edelbrock, C. S. in Smallish, L. (1990). The adolescent outcome of hyperactive children diagnosed by research criteria: II. academic, attentional, and neuropsychological status. Journal of Consulting and Clinical Psychology, 58, 580-588.

Frankel, F. in Feinberg, D. (2002). Social problems associated with ADHD vs. ODD in children referred for friendship problems. Child Psychiatry and Human Development, 33, 125-146.

Fuchs, T., Birbaumer, N., Lutzenberger, W., Gruzelier, J. H. in Kaiser, J. (2003). Neurofeedback treatment for attention-deficit/hyperactivity disorder in children: A comparison with methylphenidate. Applied Psychophysiology and Biofeedback, 28, 1-12.

Fussell, J. J., Macias, M. M. in Saylor, C. F. (2005). Social skills and behavior problems in children with disabilities with and without siblings. Child Psychiatry and Human Development, 36, 227-241.

Giedd, J. N., Castellanos, F. X., Casey, B. J., Kozuch, P., King, A. C., Hamburger, S. D. in Rapoport, J. L. (1994). Quantitative morphology of the corpus callosum in attention deficit hyperactivity disorder. The American Journal of Psychiatry, 151, 665-669.

Gillberg, C. (2003). Deficits in attention, motor control, and perception: A brief review. Archives of Disease in Childhood, 88, 904-910.

Goldwyn, R., Stanley, C., Smith, V. in Green, J. (2000). The Manchester Child Attachment Story Task: Relationship with parental AAI, SAT and child behaviour. Attachment \& Human Development, 2, 71-84.

Gostečnik, C. (2004). Relacijska družinska terapija [Relational family therapy]. Ljubljana: Brat Frančišek, Frančiškanski družinski inštitut.

Green, J., Stanley, C. in Peters, S. (2007). Disorganized attachment representation and atypical parenting in young school age children with externalizing disorder. Attachment \& Human Development, 9, 207-222.

Greene, R. W., Biederman, J., Faraone, S. V., Sienna, M. in Garcia-Jetton, J. (1997). Adolescent outcome of boys with attention-deficit/hyperactivity disorder and social disability: Results from a 4-year longitudinal follow-up study. Journal of Consulting and Clinical Psychology, 65, 758-767.

Guevremont, D. C. in Dumas, M. C. (1994). Peer relationship problems and disruptive behavior disorders. Journal of Emotional and Behavioral Disorders, 2, 164-172.

Guttmann-Steinmetz, S., Gadow, K. D., DeVincent, C. J. in Crowell, J. (2010). Anxiety symptoms in boys with autism spectrum disorder, attention-deficit hyperactivity disorder, or chronic multiple tic disorder and community controls. Journal of Autism and Developmental Disorders, 40, 1006-1016.
Hart, E. L., Lahey, B. B., Loeber, R., Applegate, B. in Frick, P. J. (1995). Developmental change in attention-deficit hyperactivity disorder in boys: A four-year longitudinal study. Journal of Abnormal Child Psychology: An Official Publication of the International Society for Research in Child and Adolescent Psychopathology, 23, 729-749.

Harvey, E., Danforth, J. S., Eberhardt McKee, T., Ulaszek, W. R. in Friedman, J. L. (2003). Parenting of children with attention-deficit/hyperactivity disorder(ADHD): The role of parental ADHD symptomatology. Journal of Attention Disorders, 7, 31-42.

Heiman, T. (2005). An examination of peer relationships of children with and without attention deficit hyperactivity disorder. School Psychology International, 26, 330-339.

Holmberg, K. in Hjern, A. (2008). Bullying and attentiondeficit-hyperactivity disorder in 10-year-olds in a Swedish community. Developmental Medicine \& Child Neurology, 50, 134-138.

Holnthaner, R. (2008). Uporaba nevrofeedbacka pri obravnavi motenj pozornosti s hiperaktivnostjo ali brez nje - ADHD/ADD [Neurofeedback in ADHD/ ADD treatment]. Psihološka obzorja, 17, 107-116.

Huss, M. in Lehmkuhl, U. (2002). Methylphenidate and substance abuse: A review of pharmacology, animal, and clinical studies. Journal of Attention Disorders, 6, S65-S71.

Johnston, C. in Mash, E. J. (2001). Families of children with attention-deficit/ hyperactivity disorder: Review and recommendations for future research. Clinical Child and Family Psychology Review, 4, 183-207.

Kadesjo, B. in Gillberg, C. (2001). The comorbidity of ADHD in the general population of Swedish schoolage children. Journal of Child Psychology and Psychiatry, 42, 487-492.

Kaplan, B. J., Crawford, S. G., Fisher, G. C. in Dewey, D. M. (1998). Family dysfunction is more strongly associated with ADHD than with general school problems. Journal of Attention Disorders, 2, 209-216.

Kendall, J. (1999). Sibling accounts of attention deficit hyperactivity disorder (ADHD). Family Process, 38, $117-136$.

Lahey, B. B. (2001). Should the combined and predominantly inattentive types of ADHD be considered distinct and unrelated disorders? Not now, at least. Clinical Psychology: Science and Practice, 8, 494-497.

Lambert, N. M. in Hartsough, C. S. (1998). Prospective study of tobacco smoking and substance dependencies among samples of ADHD and non-ADHD participants. Journal of Learning Disabilities, 31, 533-544.

Landau, S. in Moore, L. A. (1991). Social skill deficits in children with attention-deficit hyperactivity disorder. School Psychology Review, 20, 235-251.

Landau, S., Lorch, E. P. in Milich, R. (1992). Visual attention to and comprehension of television in 
attention-deficit hyperactivity disordered and normal boys. Child Development, 63, 928-937.

Lange, G., Sheerin, D., Carr, A., Dooley, B., Barton, V., Marshall, D., Mulligan, A., Lawlor, M., Belton, M. in Doyle, M. (2005). Family factors associated with attention deficit hyperactivity disorder and emotional disorders in children. Journal of Family Therapy, 27, 76-96.

Leibson, C. L., Katusic, S. K., Barbaresi, W. J., Ransom, J. in O'Brien, P. C. (2001). Use and costs of medical care for children and adolescents with and without attention-deficit/hyperactivity disorder. JAMA: Journal of the American Medical Association, 285, 60-66.

Levy, F., Hay, D. A., McStephen, M., Wood, C. in Waldman, I. D. (1997). Attention-deficit hyperactivity disorder: A category or a continuum? Genetic analysis of a large-scale twin study. Journal of the American Academy of Child \& Adolescent Psychiatry, 36, 737-744.

Lifford, K. J., Harold, G. T. in Thapar, A. (2008). Parent-child relationships and ADHD symptoms: A longitudinal analysis. Journal of Abnormal Child Psychology: An Official Publication of the International Society for Research in Child and Adolescent Psychopathology, 36, 285-296.

Lindahl, K. M. (1998). Family process variables and children's disruptive behaviour problems. Journal of Family Psychology, 12, 420-436.

Lubar, J. F., Swartwood, M. O., Swartwood, J. N. in O'Donnell, P. H. (1995). Evaluation of the effectiveness of EEG neurofeedback training for ADHD in a clinical setting as measured by changes in T.O.V.A. scores, behavioral ratings, and WISC-R performance. Biofeedback \& Self Regulation, 20, 83-99.

Lynam, D., Moffitt, T. E. in Stouthamer-Loeber, M. (1993). Explaining the relation between IQ and delinquency: Class, race, test motivation, school failure, or selfcontrol? Journal of Abnormal Psychology, 102, 187-196.

Lynskey, M. T. in Hall, W. (2001). Attention deficit hyperactivity disorder and substance use disorders: Is there a causal link? Addiction, 96, 815-822.

McGee, R. in Share, D. L. (1988). Attention deficit disorder-hyperactivity and academic failure: Which comes first and what should be treated? Journal of the American Academy of Child \& Adolescent Psychiatry, 27, 318-325.

Mick, E., Biederman, J., Faraone, S. V., Sayer, J. in Kleinman, S. (2002). Case-control study of attentiondeficit hyperactivity disorder and maternal smoking, alcohol use and drug use during pregnancy. Journal of the American Academy of Child \& Adolescent Psychiatry, 41, 378-385.

Mikami, A. Y. (2010). The importance of friendship for youth with attention-deficit/hyperactivity disorder. Clinical Child and Family Psychology Review, 13, 181-198.
Minde, K., Eakin, L., Hechtman, L., Ochs, E., Bouffard, R., Greenfield, B. in Looper, K. (2003). The psychosocial functioning of children and spouses of adults with ADHD. Journal of Child Psychology and Psychiatry, 44, 637-646.

Moffitt, T. E. (1990). Juvenile delinquency and Attention Deficit Disorder: Boys' developmental trajectories from age 3 to age 15. Child Development, 61, 893-910.

Moravec Berger, D. in Kovačič, I. (2005). Mednarodna klasifikacija bolezni in sorodnih zdravstvenih problemov za statistične namene: MKB-10: deseta revizija [International Classification of Diseases: ICD-10]. Ljubljana, SLO: Institut za varovanje zdravja Republike Slovenije.

Mostofsky, S. H., Reiss, A. L., Lockhart, P. in Denckla, M. B. (1998). Evaluation of cerebellar size in attentiondeficit hyperactivity disorder. Journal of Child Neurology, 13, 434-439.

MTA Cooperative Group. (1999). Fourteen-month randomized clinical trial of treatment strategies for attention deficit/hyperactivity disorder. Archives of General Psychiatry, 56, 1073-1086.

Nixon, E. (2001). The social competence of children with Attention Deficit Hyperactivity Disorder: A review of the literature. Child and Adolescent Mental Health, 6, 172-180.

Oosterlaan, J., Scheres, A. in Sergeant, J. A. (2005). Which executive functioning deficits are associated with $\mathrm{AD} / \mathrm{HD}, \mathrm{ODD} / \mathrm{CD}$ and comorbid $\mathrm{AD} / \mathrm{HD}+$ ODD/CD? Journal of Abnormal Child Psychology, $33,69-85$.

Pennington, B. F., Groisser, D. in Welsh, M. C. (1993). Contrasting cognitive deficits in attention deficit hyperactivity disorder versus reading disability. Developmental Psychology, 29, 511-523.

Pliszka, S. R. (2007). Pharmacologic treatment of attention-deficit/hyperactivity disorder: Efficacy, safety and mechanisms of action. Neuropsychology Review, 17, 61-72.

Pressman, L. J., Loo, S. K., Carpenter, E. M., Asarnow, J. R., Lynn, D., McCracken, J. T., McGough, J. J., Lubke, G. H., Yang, M. H. in Smalley, S. L. (2006). Relationship of family environment and parental psychiatric diagnosis to impairment in ADHD. Journal of the American Academy of Child \& Adolescent Psychiatry, 45, 346-354.

Quay, H. C. (1997). Inhibition and attention deficit hyperactivity disorder. Journal of Abnormal Child Psychology, 25, 7-13.

Rapport, M. D. in Moffitt, C. (2002). Attention deficit/ hyperactivity disorder and methylphenidate: A review of height/weight, cardiovascular and somatic complaint side effects. Clinical Psychology Review, 22, 1107-1131.

Root, R. W. II in Resnick, R. J. (2003). An update on the diagnosis and treatment of attention-deficit/ hyperactivity disorder in children. Professional Psychology: Research and Practice, 34, 34-41. 
Rossiter, T. R. in La Vaque, T. (1995). A comparison of EEG biofeedback and psychostimulants in treating attention deficit/hyperactivity disorders. Journal of Neurotherapy, 1, 48-59.

Rubia, K., Overmeyer, S., Taylor, E., Brammer, M., Williams, S. C. R., Simmons, A. in Bullmore, E. T. (1999). Hypofrontality in attention deficit hyperactivity disorder during higher-order motor control: A study with functional MRI. The American Journal of Psychiatry, 156, 891-896.

Resnick, R. J. (2005). Attention deficit hyperactivity disorder in teens and adults: They don't all outgrow it. Journal of Clinical Psychology, 61, 529-533.

Santosh, P. J. in Taylor, E. (2000). Stimulant drugs. European Child \& Adolescent Psychiatry, 9, $\mathrm{S} 27-\mathrm{S} 43$.

Satterfield, J. H., Cantwell, D. P., Lesser, L. I. in Posodin, R. L. (1972). Physiological studies of the hyperkinetic child: I. The American Journal of Psychiatry, 128, 1418-1424.

Schroeder, V. M. in Kelley, M. L. (2009). Associations between family environment, parenting practices, and executive functioning of children with and without ADHD. Journal of Child and Family Studies, 18, 227-235.

Seidman, L. J., Biederman, J., Faraone, S. V., Weber, W. in Ouellette, C. (1997). Toward defining a neuropsychology of attention deficit-hyperactivity disorder: Performance of children and adolescents from a large clinically referred sample. Journal of Consulting and Clinical Psychology, 65, 150-160.

Snider, V. E., Frankenberger, W. in Aspenson, M. R. (2000). The relationship between learning disabilities and attention deficit hyperactivity disorder: A national survey. Developmental Disabilities Bulletin, 28, 18-38.

Sorensen, L., Plessen, K. J., Nicholas, J. in Lundervold, A. J. (2011). Is behavioral regulation in children with ADHD aggravated by comorbid anxiety disorder? Journal of Attention Disorders, 15, 56-66.

Spencer, T. J. (2009). Issues in the management of patients with complex ADHD symptoms. The Journal of Pediatrics, 154, S4-S12.

Stein, M. A., Sarampote, C. S., Waldman, I. D., Robb, A. S., Conlon, C., Pearl, P. L., Black, D. O., Seymour, K. E. in Newcorn, J. H. (2003). A Dose-Response Study of OROS methylphenidate in children with attention-deficit/hyperactivity disorder. Pediatrics, $112,404-414$.

Stormont, M. (2001). Social outcomes of children with $\mathrm{AD} / \mathrm{HD}$ : Contributing factors and implications for practice. Psychology in the Schools, 38, 521-531.

Sung, V., Hiscock, H., Sciberras, E. in Efron, D. (2008). Sleep problems in children with attention-deficit/ hyperactivity disorder: Prevalence and the effect on the child and family. Archives of Pediatrics and Adolescent Medicine, 162, 336-342.
Szatmari, P., Offord, D. R. in Boyle, M. H. (1989). Ontario Child Health Study: Prevalence of attention deficit disorder with hyperactivity. Journal of Child Psychology and Psychiatry, 30, 219-230.

Takeda, T., Stotesbery, K., Power, T., Ambrosini, P. J., Berrettini, W., Hakonarson, H. in Elia, J. (2010). Parental ADHD status and its association with proband ADHD subtype and severity. The Journal of Pediatrics, 157, 995-1000.

Tomori, M. (1999). Duševne motnje v razvojnem obdobju [Developmental disorders]. V M. Tomori in S. Ziherl (ur.), Psihiatrija [Psychiatry] (str. 328-344). Ljubljana, SLO: Litterapicta, Medicinska fakulteta.

Tripp, G., Schaughency, E. A., Langlands, R. in Mouat, K. (2007). Family interactions in children with and without ADHD. Journal of Child and Family Studies, 16, 385-400.

Volkow, N. D. in Swanson, J. M. (2008). Does childhood treatment of ADHD with stimulant medication affect substance abuse in adulthood? The American Journal of Psychiatry, 165, 553-555.

Wiener, J. (2004). Do peer relationships foster behavioral adjustment in children with learning disabilities? Learning Disability Quarterly, 27, 21-30.

Wilens, T. E., Biederman, J., Mick, E., Faraone, S. V. in Spencer, T. (1997). Attention deficit hyperactivity disorder (ADHD) is associated with early onset substance abuse. Journal of Nervous and Mental Disease, 185, 475-482.

Wilens, T. E., Biederman, T. J. in Spencer, J. (2002). A review of the pharmacotherapy of adults with attention-deficit/hyperactivity disorder. Journal of Attention Disorders, 5(4), 189-202.

Zametkin, A. J., Nordahl, T. E., Gross, M., King, A. C., Semple, W. E., Rumsey, J., Hamburger, S. in Cohen, R. M. (1990). Cerebral glucose metabolism in adults with hyperactivity of childhood onset. The New England Journal of Medicine, 323, 1361-1366.

Zhang, L., Jin, X. in Zhang, Y. (2011). Effect of methylphenidate on intelligence quotient scores in Chinese children with attention-deficit/hyperactivity disorder. Journal of Clinical Psychopharmacology, 31, 51-55. 